\title{
Although it induces synchronized ovulation, hCG reduces the fertility of Santa Ines ewes submitted to TAI
}

\author{
[Embora induza a ovulação sincronizada, hCG reduz a fertilidade de ovelhas Santa Inês \\ submetidas à IATF] \\ L.M.K. Dias ${ }^{1,2}$, J.N.S. Sales ${ }^{3}$, P. Viau ${ }^{1}$, M.B.P. Barros ${ }^{1}$, S.S. Nicolau ${ }^{1}$, L.M.S. Simões ${ }^{3}$, \\ N.G. Alves ${ }^{3}$, M.A. Alonso ${ }^{1}$, R. Valentim ${ }^{1}$, C.A. Oliveira ${ }^{1}$ \\ ${ }^{1}$ Universidade de São Paulo - São Paulo, SP \\ ${ }^{2}$ Universidade de Sorocaba - Sorocaba, SP \\ ${ }^{3}$ Universidade Federal de Lavras - Lavras, MG
}

\begin{abstract}
The aim of this study was to evaluate hCG treatment on ovarian response and on pregnancy rate using a 9-day oestrus synchronization protocol in Santa Ines ewes. On a random oestrus cycle day, ewes received an intravaginal progesterone device (Primer-PR ${ }^{\circledR}$, Tecnopec, Brazil). Nine days later (Day 9), 30 $\mu \mathrm{g}$ of $\mathrm{d}-$ cloprostenol (Prolise ${ }^{\circledR}$, Syntex, Argentina) and 250IU of eCG (Folligon ${ }^{\circledR}$, Intervet, Brazil) were administered and the progesterone device was removed. This moment, the ewes were randomly assigned on two groups: Control Group and hCG Group. In the hCG Group, the ewes received 500IU of hCG (Vetecor ${ }^{\circledR}$, HertapeCalier, Spain) 24h after device removal. In the Control Group, the ewes did not receive any ovulation inductor. Control and hCG Groups ewes were inseminated $60 \mathrm{~h}$ and $48 \mathrm{~h}$ after device removal, respectively. There was no difference between the groups regarding the first ovulatory follicle diameter and the second ovulatory follicle. hCG Group ewes had shorter interval between device removal and ovulation (Control: $79.9 \pm 15.4 \mathrm{~h}$ and hCG: 54.7 $\pm 4.9 \mathrm{~h} ; \mathrm{P}=0.001$ ) and more synchronized ovulations. However, the treatment with hCG decreased the pregnancy rate after TAI $(\mathrm{P}=0,009)$. In conclusion, hCG administration improves ovulatory synchronisation, but causes a decrease in the pregnancy rate.
\end{abstract}

Keywords: progesterone, follicle, ovulation, synchronization

\section{RESUMO}

Avaliou-se o tratamento com hCG na resposta ovariana e na taxa de prenhez utilizando protocolo de sincronização do estro de nove dias em ovelhas Santa Inês. As ovelhas receberam um dispositivo intravaginal de progesterona em fase aleatória do ciclo (dia zero $=D 0$ ). No momento da remoção do dispositivo (D9), as fêmeas receberam 30 $\mu \mathrm{g}$ de d-cloprostenol (Prolise ${ }^{\circledR}$, Syntex, Argentina) e 250UI de eCG (Folligon ${ }^{\circledR}$, Intervet, Brasil). Nesse momento, as ovelhas foram aleatoriamente distribuídas em dois grupos de tratamento: controle sem indução de ovulação e tratamento com 500UI hCG para indução de ovulação. As ovelhas dos grupos controle e hCG foram inseminadas $60 \mathrm{~h}$ e $48 \mathrm{~h}$ após a remoção do dispositivo, respectivamente. Não houve diferença entre os grupos para o diâmetro do primeiro e do segundo folículo pré-ovulatório. As avelhas do grupo hCG apresentaram menor intervalo entre a remoção do dispositivo e a ovulação (grupo controle: $79.9 \pm 15.4$ h e grupo $h C G: 54.7 \pm 4.9 \mathrm{~h} ; \mathrm{P}=0.001)$ e maior sincronização das ovulações. No entanto, o tratamento com hCG diminuiu a taxa de prenhez após a IATF $(P=0,009)$. Conclui-se que, apesar de a administração de hCG aumentar a sincronização da ovulação, reduz a taxa de prenhez.

Palavras-chave: progesterona, folículo, ovulação, sincronização

\section{INTRODUCTION}

Currently, existing hormonal protocols for sheep do not efficiently synchronize ovulation (Barrett et al., 2008) to obtain high pregnancy rates with

Recebido em 19 de dezembro de 2016

Aceito em 3 de maio de 2017

E-mail: lilikirsch@gmail.com fixed time insemination (Thatcher et al., 2001). Thus, artificial insemination programs in ewes demand oestrus detection for insemination, which elicits variable results and increases handling, food and management costs (Reyna et al., 2007). 
In general, protocols based on the use of a progesterone source are associated with prostaglandin and eCG (Abecia et al., 2012). In the literature, there is a tendency of decreasing the progestagen maintenance period (Ungerfeld and Rubianes, 1999), which was traditionally used for 12 to 14 days, because longer treatment periods can cause lower fertility by disrupting follicular development (Vinoles et al., 2001; Husein and Ababneh, 2008). Thus, the main goal was to identify the ideal period of progestagen maintenance and its association with an ovulation induction agent to ensure an efficient synchronization, which would enable the utilization of the fixed time insemination technique.

Due to the similarity between the hCG and LH molecules, both bind to the same receptor (Lapthorn et al., 1994). Consequently, hCG has been used in hormonal protocols as an ovulation induction agent in different species (Diaz et al., 1998; Ginther et al., 2009). In ewes, hCG administration (500UI) increased ewes with multiple births and prolificacy, although lambing rates was decreased (Zamiri and Hosseini, 1998). In addition, other beneficial effects such as an increase in progesterone concentration (Shabankareh et al., 2012) and indirectly, an improvement in foetal development (Khan et al., 2003,2007 ) have been reported.

There has been a great number of ovine breeds and variation among them regarding their response to synchronization protocols worldwide. Consequently, the study of follicular dynamics is essential on a specific breed to achieve an efficient hormonal protocol (Ali et al., 2006). The Santa Ines breed, which is considered to be naturalized, has adapted to all climates, is highly resistant to endoparasites and diseases and has a great importance in the Brazilian ovine industry (Pedrosa et al., 2010). However, to the best of our knowledge, there has been no previous study using a hormonal protocol and follicular dynamics on Santa Ines ewes. Thus, there is a need to verify the ovulatory wave, the preovulatory follicular diameter and ovulation time, for the application of artificial insemination at a fixed time. Therefore, the aim of this study was to evaluate hCG treatment on ovarian response (experiment 1) and on prolificacy and on pregnancy rate (experiment 2) using a 9-day oestrus synchronization protocol in Santa Ines ewes. The hypothesis is that hCG induces earlier and more synchronized ovulations and improves the pregnancy rate in Santa Ines ewes.

\section{MATERIAL AND METHODS}

The experiment 1 was performed in the Animal Reproduction Department of São Paulo University (FMVZ-USP). Nine, 3-5-year-old, healthy, body condition scores of 3 and 4 (on a scale of 1 to 5; Menchaca et al., 2009) cycling Santa Ines ewes were used. The animals were kept confined, fed two times a day with a hay and pellet feed-based diet and mineral salt and water ad libitum. The study was performed during the breeding season. All experiments were performed in accordance to the FMVZ-USP Animal Experimentation Bioethics Committee.

The experimental design used was randomized with repeated measures over time. At the beginning of the experiment, ewes had a progesterone concentration above $1 \mathrm{ng} / \mathrm{ml}$ and the presence of the corpus luteum. On a random oestrus cycle day (Day 0), ewes received an intravaginal $0.36 \mathrm{~g}$ progesterone device (Primer$\mathrm{PR}^{\circledR}$, Tecnopec, Brazil). On day 9, the progesterone device was removed, $30 \mu \mathrm{g}$ of dcloprostenol (Prolise ${ }^{\circledR}$, Syntex, Argentina) and 250UI of eCG were administered (Folligon ${ }^{\circledR}$, Intervet, Netherland). Simultaneously at the progesterone device removal (Day 9), ewes were randomly allocated to one of two treatment groups (Control Group and the hCG Group). In the hCG Group, 500IU of hCG i.m. (Vetecor ${ }^{\circledR}$, HertapeCalier, Spain) were administered $24 \mathrm{~h}$ after device removal (Day 10). In the Control Group, the ewes did not receive any ovulation induction agent. After a 30-day interval, a replicate of the experiment was performed (phase 2 ), in which the Control Group ewes were allocated into the hCG Group and vice versa. The dose of hCG (500IU) administered was based on the study of Zamiri and Hosseini (1998). Timing of hCG administration was performed in ewe with follicular diameter that responds to an ovulation inducer (Martinez et al., 2015). On the day of the device removal, the ewes were exposed to adult rams in order to identify and determine the oestrus duration, at a rate of one ewe/one male. The ram was placed with each one of the ewes at 10:00AM, 06:00PM and 12:00PM per 5 days. The beginning and end 
of the oestrus were calculated using the mean of the last two times when the behavioral changes were detected in the acceptance of mounting.

Ultrasonographic exams (US) of both ovaries were performed at different moments between the first and second part of the experiment for evaluation of preovulatory follicular dynamics. During the first phase, US exams were performed every $12 \mathrm{~h}$ after device removal (Day 9) until ovulation to evaluate the final growth of visualized follicles and ovulation. During the second phase, US exams were performed daily to determine the onset of follicular emergence and potential follicle regression since Day 0 until their removal nine days after (Day 9). From Day 9, US exams were performed every $12 \mathrm{~h}$ until ovulation. A real-time ultrasonic scanner in $\mathrm{B}$ mode equipped with a $5.0 \mathrm{MHz}$ liner transducer (ALOKA-SSD500, Berger, Brazil) was used. This technique has been validated for monitoring ovarian follicular dynamics in sheep (Ravindra et al., 1994). The number, diameter, and relative position of all follicles $\geq 3 \mathrm{~mm}$ were sketched in the ovary schematic maps. The moment of follicular wave emergence was determined by retrospective observation of the ovulatory follicle until it had an initial diameter of $3 \mathrm{~mm}$. Ovulation was defined as the disappearance of the greater follicle previously visualized, with further confirmation according to the corpus luteum visualization. The moment of ovulation was estimated using the simple mean between the time of last visualization of the follicle and the first time of ovulation was detected. The ovulation efficiency rate was determined by dividing the number of formed $\mathrm{CL}$ and the number of ovulatory follicles (greater than $4 \mathrm{~mm}$ ). Twelve days after device removal, the CL diameters were measured.

Blood samples were collected via a puncture of the jugular vein in the morning (9:00AM) on days $0,1,3,4,6,8,10,12,14,17,19$ and 21 of the device placement. The samples were refrigerated $\left(4^{\circ} \mathrm{C}\right)$ for approximately 1 hour, centrifuged $(1500 \times g$ for $20 \mathrm{~min})$, and stored at $20^{\circ} \mathrm{C}$ until assayed for P4. Serum concentrations of P4 were evaluated from unextracted serum using an antibody-coated-tube RIA kit (Coat-ACount ${ }^{\circledR}$, Diagnostic Products Corporation, Los Angeles, CA, USA), which has been previously validated by Meikle et al. (2001). The progesterone assay sensibility was $0.01 \mathrm{ng} / \mathrm{mL}$, the intra-assay coefficient of variation for low values was $3.21 \%$, and the high values were $1.93 \%$.

Experiment 2 was a field trial that was conducted on a commercial farm in northwestern Brazil during reproduction season. A total of 129 Santa Ines sheep were used with a body condition score of 2-3 (scale 1-5). The animals were divided randomly in two groups Control Group $(n=67)$ and hCG Group $(n=62)$. The treatments were carried out in the same manner as experiment 1 . Females from Control Group and hCG Group were inseminated between 60-61 h and 48-49h after the removal of the device, respectively. These TAIs were defined in order to that the inseminations were performed 10 and 16 hours before ovulation of the ewes that received (Quirke et al., 1979) or not the ovulation inducer (Dias et al., 2015).

Semen of five rams of the Dorper breed of known fertility was collected with the artificial vagina method with the help of ewes in estrous, thirty minutes before the determined period for each insemination. Immediately after each collection the semen was evaluated by microscope for determination of progressive motility and vigor. All semen collected was mixed to form a pool and diluted 2:1 (Botu-Bov, Nutricell, Brazil) with a final concentration of $0.9 \times 10 \% \mathrm{ml}$. After this procedure, the semen remained in a tube protected from sun light and in room temperature. At the moment of insemination, the ewes were placed with their heads down and semen $(0.5 \mathrm{ml})$ was deposited in the cervix using a speculum with an attached light source and a pipette tip (Minitub, Porto Alegre, Brazil). Semen was deposited in the genital tract as deeply as possible without harming the cervical epithelia. Gestation diagnosis was performed 35 days after artificial insemination with a rectal sonogram exam (Aloka SSD 500, Aloka, Japan). Pregnancy rate was determined by the total of pregnant ewes over the total of ewes. Prolificacy was determined by the number of lambs born of pregnant ewes.

Statistical analyses were performed using the Statistical Analysis System for Windows SAS software (Statistical..., 2001). Data were tested for normality of the residues and analyzed using the UNIVARIATE procedure and subjected to 
Bartlett's test to assess the homogeneity of variances. Data that did not meet the assumptions of the analysis of variance were transformed (progesterone concentration - square root). The GLM procedure with Tukey adjustment was then used to determine the significant differences among groups. Non-parametric distribution variables were evaluated using Mann-Whitney test and the GENMOD procedure of SAS®. Dispersion of ovulations was evaluated using Bartlett test. All values were expressed as the mean \pm SEM. Binomial data were analyzed by a multivariate logistic regression using the GLIMMIX procedure of SAS. Significant differences between tested variables were established at $\mathrm{P}<0.05$.

\section{RESULTS}

On the first phase of the experiment 1 , all ewes were used to determinate the moment of ovulation. On the second phase, it was not possible to visualize the moment of ovulation in one of the ewes (hCG Group). Then, data this ewe was not considered for moment of ovulation. Only $37.5 \%$ of the ewes of the hCG group showed estrus. Moreover, ewes from hCG Group had a shorter interval between oestrus onset and ovulation $(\mathrm{P}=0.003)$ and between device removal and ovulation $(\mathrm{P}=0.001)$. In Control Group ewes, there was a greater dispersion $(\mathrm{P}=0.02)$ of ovulations in relationship to progesterone device removal (Table 1).

There was no effect of treatment on the largest follicle (LF) diameter on the progesterone device removal day $(\mathrm{P}=0.68)$, on the first ovulatory follicle diameter $(\mathrm{P}=0.09)$ and on the second ovulatory follicle diameter $(\mathrm{P}=0.08)$, on $\mathrm{LF}$ diameter at the onset of oestrus $(\mathrm{P}=0.54)$, on $\mathrm{LF}$ diameter at hCG administration day $(\mathrm{P}=0.86)$ and on follicular growth $(\mathrm{P}=0.35)$ (Table 1). In addition, hCG administration time did not interfere with follicular development because there was no difference between groups in the maximum diameter in the first and second preovulatory follicles. Moreover, there was no difference on the largest ovulatory follicle diameter $(\mathrm{P}=0.4)$ between single $(5.96 \pm 1.04 \mathrm{~mm})$ or double ovulation ewes $(5.49 \pm 0.43 \mathrm{~mm})$ (Table $1)$. When considering only double ovulation ewes, the largest ovulatory follicle diameter $(5.49 \pm 0.43 \mathrm{~mm})$ was greater $(\mathrm{P}=0.01)$ than the second largest ovulatory follicle $(4.94 \pm 0.55 \mathrm{~mm})$. One ewe from the Control Group and one ewe from the hCG Group presented a cyst after treatment, and their diameters were 11.0 and $8.9 \mathrm{~mm}$.

The Control Group animals showed a higher proportion of oestrus behavior $(\mathrm{P}=0.009)$. However, there was no difference between treatments regarding the average interval from device removal and oestrus onset $(\mathrm{P}=0.11)$ and on oestrus period $(\mathrm{P}=0.72)$. There was no difference between groups concerning the ovulation number per ewe. The overall ovulation rate considering all of the animals was $84.61 \%$ (33/39) and the ovulation per ewe was 1.94 ovulations (Table 1). A single ovulation occurred in $17.65 \%(3 / 17)$ of the ewes, double ovulation in $70.59 \%(12 / 17)$ and triple ovulation in $11.76 \%$ (2/17). Considering both groups, there was a greater number of ovulations $(\mathrm{P}=0.03)$ on the right ovary (63.7\% vs. $36.7 \%)$.

The corpus luteum area was similar $(\mathrm{P}=0.94)$ between treatments (Table 1). In addition, it was noted that the CL formed from the first ovulatory follicle $\left(\mathrm{CL} 1=10.8 \pm 3.2 \mathrm{~mm}^{2}\right)$, which was greater than $(\mathrm{P}=0.02)$ the $\mathrm{CL}$ formed from the second ovulatory follicle $\left(\mathrm{CL} 2=7.8 \pm 3.0 \mathrm{~mm}^{2}\right)$ in double ovulating ewes.

The serum progesterone concentration between D0 and D8 did not differ $(\mathrm{P}=0.49)$ between treatments. It was $11.06 \pm 4.82 \mathrm{ng} / \mathrm{ml}$ in the Control Group and $9.74 \pm 4.37 \mathrm{ng} / \mathrm{ml}$ in the $\mathrm{hCG}$ Group. However, on D14 and D16, a higher concentration was detected in the hCG Group (Figure 1).

There was a lower pregnancy rate in the animals treated with hCG $(\mathrm{P}=0.009)$, with no difference between the groups as far as prolificacy (Table 2). 
Although it induces synchronized...

Table 1. Effect of hCG administration on ovulation induction using the 9-Day synchronisation protocol in Santa Ines cycling ewes

\begin{tabular}{llll}
\hline & Control & hCG & P \\
\hline LF on progesterone device removal $(\mathrm{mm})$ & $4.6 \pm 1.0$ & $4.4 \pm 0.7$ & 0.68 \\
First ovulatory follicle (mm) & $5.8 \pm 0.3$ & $5.4 \pm 0.7$ & 0.09 \\
Second ovulatory follicle (mm) & $5.4 \pm 0.8$ & $4.7 \pm 0.5$ & 0.08 \\
LF on the onset of oestrus (mm) & $5.4 \pm 0.5$ & $5.1 \pm 0.7$ & 0.54 \\
LF on hCG administration day (mm) & $4.3 \pm 1.1$ & $4.2 \pm 1.1$ & 0.86 \\
\hline Oestrus rate (\%) & 100.0 & 37.5 & 0.009 \\
\hline$P_{4}$-removal-oestrus interval (hours) & $47.4 \pm 15.0$ & $32.0 \pm 0.0$ & 0.11 \\
Oestrus period (hours) & $36.2 \pm 18.6$ & $38.6 \pm 30.6$ & 0.72 \\
Oestrus ovulation interval (hours) & $32.6 \pm 10.9$ & $20.0 \pm 3.0$ & 0.003 \\
P $_{4}$ removal-ovulations interval & $79.9 \pm 15.4$ & $54.7 \pm 4.9$ & 0.001 \\
Follicular growth (mm/day) & $0.7 \pm 0.2$ & $0.8 \pm 0.2$ & 0.35 \\
Ovulation rate (\%) & 94.7 & 75.0 & 0.50 \\
Ovulation mean/ewe & 2.0 & 1.9 & 0.72 \\
Corpus luteum (mm ${ }^{2}$ ) & $9.5 \pm 3.8$ & $9.4 \pm 2.9$ & 0.94 \\
\hline
\end{tabular}

LF - Largest Follicle; $\mathrm{P}_{4}$ - Progesterone

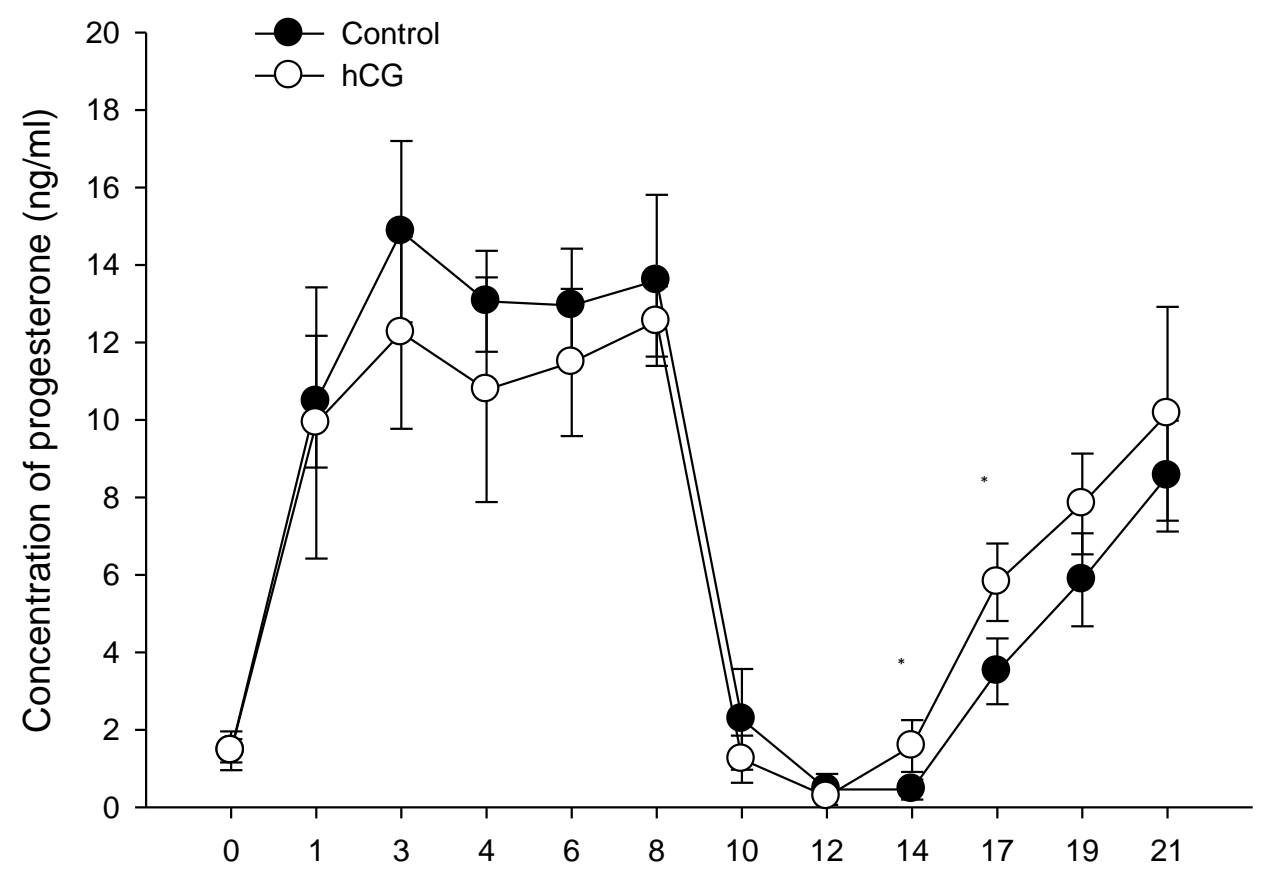

Figure 1. Progesterone concentration in ewes subjected to ovulation synchronisation using an intravaginal progesterone device. *Significantly different $(\mathrm{P}<0.05)$.

Table 2. Pregnancy rate between Control Group and hCG Group submitted to the 9 days estrous synchronization protocol

\begin{tabular}{l|l|l|l}
\hline Treatment & Control Group & hCG Group & P \\
\hline Pregancy rate (\%) & 56.7 & 33.9 & 0.009 \\
Prolificity & $(38 / 67)$ & $(21 / 62)$ & 0.43 \\
\hline
\end{tabular}




\section{DISCUSSION}

The hypothesis that hCG administration induces more synchronized ovulations in Santa Ines ewes was confirmed. In the present study, hCG Group promoted an earlier and more synchronized ovulation $(54.7 \pm 4.0 \mathrm{~h})$, and it did not alter the ovulation rate. However, the hypothesis that hCG increases the pregnancy rate was not accepted, as there was decrease in the pregnancy rate in ewes hCG treatment.

hCG administration time did not interfere with follicular development because there was no difference between groups in the maximum diameter in the first and second preovulatory follicles. These results were consistent with those found in the literature in the normal estrous cycle of ewe, which indicates that hCG administration did not interfere final follicular diameter (Toosi et al., 2009; Wu et al., 2009), despite of follicular diameter is not the only health and viability indicator of the ovulated oocyte (Seekallu et al., 2010).

There was no difference detected in the mean progesterone concentration after device removal between groups, which indicates that hCG promoted an earlier ovulation and thus, the CL in the hCG Group was formed before than the CL in the Control Group, causing a higher progesterone concentration on specific days after ovulation compared with the non-treated group. However, hCG caused an early increase in progesterone concentration that was not necessarily higher than the Control Group. This early increase in progesterone concentration can contribute to the improvement in the efficiency of the pregnancy maternal recognition process, which occurs around day 13 in ewes (Silvia et al., 1984).

In double ovulating ewes, the largest ovulatory follicle diameter was greater than the second largest ovulatory follicle. This last result was confirmed in the present study with the difference in corpus luteum diameter (CL1 and CL2) in double ovulating ewes, thus, corroborating the hypothesis of attenuated follicular dominance in the ovulatory wave in ovine (Menchaca et al., 2010). As previously described by Menchaca et al. (2010), after the emergence one, two or three follicles continued their growth until the preovulatory stage.
The overall ovulation rate considering all of the animals was $84.6 \%$ (33/39) and the ovulation per ewe was 1.94 ovulations. These results were different from those found by Khan et al. (2003), where hCG-treated animals demonstrated an increased ovulation rate. Despite this, ovulation rate of hCG-treated ewe was satisfactory (1.9 ovulations /ewe) and relatively high in the control group (2.0 ovulations/ewe). In addition, hCG was used as an ovulatory inducer and could interfere only in this physiological process but not in the number of dominant follicles present at the time of hCG administration, which would increase the ovulation rate. This was most likely due to the differences in breed, animal's age and protocol used between studies. Moreover, the cyst formation rate in the present study was consistent with the rates found in the literature (Vinoles et al., 2001; Barrett et al., 2004) for ewes subjected to hormonal protocols, particularly with the use of eCG.

The higher oestrus behavioral rate in the Control Group was detected in previous experiment when ovulation was induced with GnRH or hCG (Quirke et al., 1979). This most likely occurred due to an early peak of LH caused by exogenous induction. In bovine, efficient ovulation synchronization protocols enable the utilization of fixed time insemination, without the need of oestrus detection (Keskin et al., 2010). In the Control Group, the intervals between device removal and onset of oestrus (Barrett et al., 2004; Husein and Ababneh, 2008) and device removal and ovulation (Barrett et al., 2004; Wu et al., 2009) corroborate with studies performed by another authors.

hCG treatment reduced the pregnancy rates of ewes of the present study. This finding corroborates with that observed in ewes (Zamiri and Hosseini, 1998) and in cows (Marquezini et al., 2011). However, other studies (Kaya et al., 2013; Khan et al., 2003) have reported that the use of hCG in ewes increased in prolificacy, unlike the present study, probably from differences in breeds and hormonal protocol used. In addition, TAI in ewes of hCG group AI was performed closer to ovulation, reducing fertility because sperm should spend enough time in female genital tract to become capacitated to oocytes fertilization (Cline et al., 2001). Despite this, satisfactory pregnancy rate (up to $75 \%$ ) has been observed in ewe submitted to AI $24 \mathrm{~h}$ 
Although it induces synchronized...

before until $5 \mathrm{~h}$ after ovulation (Findlater et al., 1991; Husein et al., 1996). The hypothesis pointed out that the decrease in pregnancy rates are related with the alteration caused by hCG in the period of proestrus with main target: cervix, oviduct, uterus and oocyte. A threshold dose of estradiol higher exists in which an ewe will express estrous behavior (Ben Said et al., 2007). With an earlier increase of LH levels and fast ovulation, there was a shorter period of estradiol liberation by the dominant follicle and cerebral awareness showed in this study by the little manifestation of estrous of the hCG Group. This may have caused a deficiency in the estradiol and progesterone receptors formation in the endometrial cells (Zelinski et al., 1980), which may have reduced ewe fertility. Moreover, mammal oviduct is one of the target tissues for the ovarian steroids - estradiol and progesterone. The epithelial lining of the oviduct is sensible to hormonal fluctuations that occur during estrous and pregnancy. Gametes transportation, fertilization and the beginning of embryonic development occur in an oviduct dominated by estradiol (Murray, 1992). The shorter period of estradiol liberation caused by the administration of hCG may have jeopardized as well the production of essential proteins for embryonic development in ewe oviduct.

Another hypothesis already reported (Yavas and Walton, 2000) is that induction with hCG in cows would cause ovulation of the smaller follicles leading to the development of corpus luteum and therefore with less concentration of progesterone (Vasconcelos et al., 2001). This was not shown in this study, as there was no difference in the diameter of preovulatory follicles, corpus luteum and progesterone concentration between the groups.

\section{CONCLUSIONS}

hCG administration 24 hours after P4 device removed promoted earlier and more synchronized ovulations in Santa Inês ewe. However, ewe hCG treatment had lower occurrence of estrus and pregnancy rate.

\section{ACKNOWLEDGEMENTS}

We acknowledge the Fundação de Amparo à Pesquisa do Estado de São Paulo (FAPESP), Fundação de Amparo à Pesquisa do Estado de
Minas Gerais (FAPEMIG) and Conselho Nacional de Desenvolvimento Científico e Tecnológico $(\mathrm{CNPq})$ for providing financial support.

\section{REFERENCES}

ABECIA, J.A.; FORCADA, F.; GONZALEZBULNES, A. Hormonal control of reproduction in small ruminants. Anim. Reprod. Sci., v.130, p.173-179, 2012.

ALI, A.; DERAR, R.; HUSSEIN, H. Seasonal variation of the ovarian follicular dynamics and luteal functions of sheep in the subtropics. Theriogenology, v.66, p.463-469, 2006.

BARRETT, D.M.; BARTLEWSKI, P.M.; BATISTA-ARTEAGA, M. et al. Ultrasound and endocrine evaluation of the ovarian response to a single dose of $500 \mathrm{IU}$ of eCG following a 12-day treatment with progestogen-releasing intravaginal sponges in the breeding and nonbreeding seasons in ewes. Theriogenology, v.61, p.311-327, 2004.

BARRETT, D.M.; BARTLEWSKI, P.M.; DUGGAVATHI, R. et al. Synchronization of follicular wave emergence in the seasonally anestrous ewe: the effects of estradiol with or without medroxyprogesterone acetate. Theriogenology, v.69, p.827-836, 2008.

BEN SAID, S.; LOMET, D.; CHESNEAU, D. et al. Differential estradiol requirement for the induction of estrus behavior and the luteinizing hormone surge in two breeds of sheep. Biol. Reprod., v.76, p.673-680, 2007.

CLINE, M.A.; RALSTON, J.N.; SEALS, R.C.; LEWIS, G.S. Intervals from norgestomet withdrawal and injection of equine chorionic gonadotropin or P.G. 600 to estrus and ovulation in ewes. J. Anim. Sci., v.79, p.589-594, 2001.

DIAS, L.M.; BARROS, M.B.; VIAU, P. et al. Effect of a new device for sustained progesterone release on the progesterone concentration, ovarian folicular diameter, time of ovulation ande pregnancy rate of ewes. Anim. Reprod. Sci., v.155, p.56-63, 2015.

DIAZ, T.; SCHMITT, E.J.; SOTA, R.L. et al. Human chorionic gonadotropin-induced alterations in ovarian follicular dynamics during the estrous cycle of heifers. J. Anim. Sci., v.76, p.1929-1936, 1998. 
FINDLATER, R.C.F.; HARESIGN, W.; CURNOCK, R.M.; BECK, N F.G. Evaluation of intrauterine insemination of sheep with frozen semen: Effects of time of insemination and semen dose on conception. Anim. Prod., v.53, p.89-96, 1991.

GINTHER, O.J.; BEG, M.A.; GASTAL, E.L. et al. Treatment with human chorionic gonadotropin (hCG) for ovulation induction is associated with an immediate 17beta-estradiol decrease and a more rapid LH increase in mares. Anim. Reprod. Sci., v.114, p.311-317, 2009.

HUSEIN, M.Q.; ABABNEH, M.M. A new strategy for superior reproductive performance of ewes bred out-of-season utilizing progestagen supplement prior to withdrawal of intravaginal pessaries. Theriogenology, v.69, p.376-383, 2008.

HUSEIN, M.Q.; ABABNEH, M.M.; CRABO, B.G.; WHEATON, J.E. Out-of-season breeding of ewes using transcervical artificial insemination. Sheep Goat Res. J., v.12, p.39-45, 1996

KAYA, S.; KAÇAR, C.; KAYA, D. et al. The effectiveness of supplemental administration of progesterone with GnRH, hCG and PGF $2 \alpha$ on the fertility of Tuj sheep during the non-breeding season. Small Ruminant Res., v.113, p.365-370, 2013.

KESKIN, A.; YILMAZBAS-MECITOGLU, G.; GUMEN, A. et al. Effect of hCG vs. GnRH at the beginning of the Ovsynch on first ovulation and conception rates in cyclic lactating dairy cows. Theriogenology, v.74, p.602-607, 2010.

KHAN, T.H.; BECK, N.F.; KHALID, M. The effects of GnRH analogue (buserelin) or hCG (Chorulon) on Day 12 of pregnancy on ovarian function, plasma hormone concentrations, conceptus growth and placentation in ewes and ewe lambs. Anim. Reprod. Sci., v.102, p.247257, 2007.

KHAN, T.H.; HASTIE, P.M.; BECK, N.F. et al. hCG treatment on day of mating improves embryo viability and fertility in ewe lambs. Anim. Reprod. Sci., v.76, p.81-89, 2003.

LAPTHORN, A.J.; HARRIS, D.C.; LITTLEJOHN, A. et al. Crystal structure of human chorionic gonadotropin. Nature, v.369, p.455-461, 1994.
MARQUEZINI, G.H.; DAHLEN, C.R.; BIRD, S.L. et al. Administration of human chorionic gonadotropin to suckled beef cows before ovulation synchronization and fixed-time insemination: replacement of gonadotropinreleasing hormone with human chorionic gonadotropin. J. Anim. Sci., v.89, p.3030-3039, 2011.

MARTINEZ, M.F.; MCLEOD, B.; TATTERSFIELD, G. et al. Successful induction of oestrus, ovulation and pregnancy in adult ewes and ewe lambs out of the breeding season using a GnRH+progesterone oestrus syncronisation protocol. Anim. Reprod. Sci., v.155, p.28-35, 2015.

MEIKLE, A.; FORSBERG, M.; GARÓFALO, E.G. et al. Circulating gonadotrophins and follicular dynamics in anestrous ewes after treatment with estradiol-17ß. Anim. Reprod. Sci., v.67, p.79-90, 2001.

MENCHACA, A.; VILARINO, M.; CRISPO, M. et al. New approaches to superovulation and embryo transfer in small ruminants. Reprod. Fertil. Dev., v.22, p.113-118, 2010.

MENCHACA, A.; VILARINO, M.; PINCZAK, A. et al. Progesterone treatment, FSH plus eCG, GnRH administration, and Day 0 Protocol for MOET programs in sheep. Theriogenology, v.72, p.477-483, 2009.

MURRAY, M.K. Biosynthesis and immunocytochemical localization of an estrogendependent glycoprotein and associated morphological alterations in the sheep ampulla oviduct. Biol. Reprod., v.47, p.889-902, 1992.

PEDROSA, V.B.; SANTANA JR, M.L.; OLIVEIRA, P.S. et al. Population structure and inbreeding effects on growth traits of Santa Inês sheep in Brazil. Small Ruminant Res., v.93, p.135-139, 2010.

QUIRKE, J.F.; JENNINGS, J.J.; HANRAHAN, J.P.; GOSLING, J.P. Oestrus, time of ovulation, ovulation rate and conception rate in progestogen-treated ewes given GnRH, GnRH analogues and gonadotrophins. J. Reprod. Fertil., v.56, p.479-488, 1979.

RAVINDRA, J.P.; RAWLINGS, N.C.; EVANS, A.C. et al. Ultrasonographic study of ovarian follicular dynamics in ewes during the oestrous cycle. J. Reprod. Fertil., v.101, p.501-509, 1994. 


\section{Although it induces synchronized...}

REYNA, J.; THOMSON, P.C.; EVANS, G. et al. Synchrony of ovulation and follicular dynamics in merino ewes treated with GnRH in the breeding and non-breeding seasons. Reprod. Domest. Anim., v.42, p.410-417, 2007.

SEEKALLU, S.V.; TOOSI, B.M.; GRAZULBILSKA, A.T. et al. Markers of ovarian antral follicular development in sheep: comparison of follicles destined to ovulate from the final or penultimate follicular wave of the estrous cycle. Reproduction, v.140, p.559-568, 2010.

SHABANKAREH, H.K.; SEYEDHASHEMI, S.B.; TORKI, M. et al. Effects of repeated administration of hCG on follicular and luteal characteristics and serum progesterone concentrations in eCG-superovulated Sanjabi ewes. Trop. Anim. Health Prod., v.44, p.18651871, 2012.

SILVIA, W.J.; FITZ, T.A.; MAYAN, M.H. et al. Cellular and molecular mechanisms involved in luteolysis and maternal recognition of pregnancy in the ewe. Anim. Reprod. Sci., v.7, p.57-74, 1984.

STATISTICAL analysis system. Version 9.1. Cari: SAS, 1991.

THATCHER, W.W.; MOREIRA, F.; SANTOS, J.E. et al. Effects of hormonal treatments on reproductive performance and embryo production. Theriogenology, v.55, p.75-89, 2001.

TOOSI, B.M.; SEEKALLU, S.V.; PIERSON, R.A. et al. Evaluation of the ultrasound image attributes of developing ovarian follicles in the four follicular waves of the interovulatory interval in ewes. Theriogenology, v.72, p.902909, 2009.
UNGERFELD, R.; RUBIANES, E. Effectiveness of short-term progestogen primings for the induction of fertile oestrus with eCG in ewes during late seasonal anoestrus. Anim. Sci., v.68, p.349-353, 1999.

VASCONCELOS, J.L.; SARTORI, R.; OLIVEIRA, H.N. et al. Reduction in size of the ovulatory follicle reduces subsequent luteal size and pregnancy rate. Theriogenology, v.56, p.307314, 2001.

VINOLES, C.; FORSBERG, M.; BANCHERO, G. et al. Effect of long-term and short-term progestagen treatment on follicular development and pregnancy rate in cyclic ewes. Theriogenology, v.55, p.993-1004, 2001.

WU, D.; BARRETT, D.M.; RAWLINGS, N.C. et al. Relationships of changes in ultrasonographic image attributes to ovulatory and steroidogenic capacity of large antral follicles in sheep. Anim. Reprod. Sci., v.116, p.73-84, 2009.

YAVAS, Y.; WALTON, J.S. Induction of ovulation in postpartum suckled beef cows: a review. Theriogenology, v.54, p.1-23, 2000.

ZAMIRI, M.J.; HOSSEINI, M. Effects of human chorionic gonadotropin (hCG) and phenobarbital on the reproductive performance of fat-tailed Ghezel ewes. Small Ruminant Res., v.30, p.157$161,1998$.

ZELINSKI, M.B.; HIROTA, N.A.; KEENAN, E.J. et al. Influence of exogenous estradiol-17 beta on endometrial progesterone and estrogen receptors during the luteal phase of the ovine estrous cycle. Biol. Reprod., v.23, p.743-751, 1980. 